\title{
The Readiness of Geography Teacher Trainees in Gamification
}

\section{Approach}

\section{Hanifah MAHAT ${ }^{1}$ \\ Universiti Pendidikan \\ Sultan Idris, Perak, MALAYSIA}

\section{Yazid SALEH ${ }^{5}$ \\ Universiti Pendidikan \\ Sultan Idris, Perak, \\ MALAYSIA}

\author{
Mohmadisa \\ HASHIM $^{2}$ \\ Universiti Pendidikan \\ Sultan Idris, Perak, \\ MALAYSIA \\ Nur HAMID 6 \\ Universitas Islam Negeri \\ Walisongo, Semarang, \\ INDONESIA
}

\author{
Saiyidatina Balkhis \\ NORKHAIDI $^{3}$ \\ Universiti Pendidikan \\ Sultan Idris, Perak, \\ MALAYSIA
Nur Hidayah
BAHARUDIN ${ }^{7}$
Sultan Idris, Perak,
MALAYSIA \\ Universiti Pendidikan
}

\author{
Nasir NAYAN ${ }^{4}$ \\ Universiti Pendidikan Sultan \\ Idris, Perak, MALAYSIA
}
Nurul Afifah Mohd
FAUDZI $^{8}$

Universiti Pendidikan Sultan

Idris, Perak, MALAYSIA

\footnotetext{
${ }^{1}$ Corresponding author: Assist. Prof. Dr. Hanifah MAHAT, Department of Geography \& Environment, Faculty of Human Science, Unive rsiti Pendidikan Sultan Idris, Perak, MALAYSIA. hanifah.mahat[at] upis.edu.my ORCID: 0000-0003-0756-6907

${ }^{2}$ Dr., Department of Geography \& Environment, Faculty of Human Science, Universiti Pendidikan Sultan Idris, Perak, MALAYSIAmohmadisa [at] upsi.edu.my. ORCID: 0000-0001-6364-7918

${ }^{3}$ Department of Geography \& Environment, Faculty of Human Science, Universiti Pendidikan Sultan Idris, Perak, Malaysia,ORCID: 0000-0002-4571-4619

${ }^{4}$ Department of Geography \& Environment, Faculty of Human Science, Universiti Pendidikan Sultan Idris, Perak, Malaysia, ORCID: 0000-0002-4571-4619

${ }^{5}$ Department of Geography \& Environment, Faculty of Human Science, Universiti Pendidikan Sultan Idris, Perak, Malaysia, ORCID: 0000-0003-1603-9025

${ }^{6}$ Department of Islamic Community Development, Universitas Islam Negeri Walisongo, Semarang, Indonesia, ORCID: 0000-0002-7447-5872

${ }^{7}$ Faculty of Human Science, Universiti Pendidikan Sultan Idris, Perak, Malaysia, ORCID: 0000-0002-7072-2493

${ }^{8}$ Department of Geography \& Environment, Faculty of Human Science, Universiti Pendidikan Sultan Idris, Perak, Malaysia, ORCID: 0000-0002-3407-2002
}

\section{Abstract}

This study aims to examine the use of the gamification approach in teacher training and learning sessions. The three main variables that are the focus of the study are gamification knowledge, gamification skills, and the use of gamification among Geography trainee teachers at the Universiti Pendidikan Sultan Idris. Survey methods involving questionnaires were used in this study. The study's sample consisted of 86 trainee teachers from sixth and seventh semester students in the Geography Bachelor of Education programme. The study sample was taken using a simple random sampling technique. This study focusses on examining the level of gamification knowledge, gamification skills, and use of gamification among Geography trainee teachers. Furthermore, the study was designed to examine each variable's differences according to gender and finally to analyse each study variable's relationship. This study used descriptive statistical analysis (frequency, mean, standard deviation, and percentage) and inferential analysis Pearson correlation. Findings show that the level of knowledge of the gamification approach is high $(M=4.08, S D=0.46)$. The skill level is also high $(M=4.13, S D=0.47)$ as well as the level of use $(M=3.82, S D=0.84)$. Pearson correlation analysis showed a moderate positive correlation between knowledge and gamification approach skills $(\mathrm{r}=0.385, \mathrm{p}=$ $0.000, p<0.01)$. Next, the correlation results showed a moderate positive correlation between use and gamification approach knowledge $(r$ $=0.329, \mathrm{p}=0.002, \mathrm{p}<0.01)$ while there was a strong positive correlation between use and gamification approach skills $(\mathrm{r}=0.670, \mathrm{p}=0.000$, $\mathrm{p}<0.01$ ). In conclusion, this study shows that trainee teachers often use the gamification approach during teaching and learning (T\&L). The study's implications show that teachers' gamification approach needs to be implemented in line with 21st-century learning goals.

\section{Keywords}

Teaching, Geography, Teacher Trainees, Gamification 
The economic, social, and political progress of a country depends on education and the higher level of knowledge of its people. History has proven that a nation with a high level of knowledge is a civilized and developed nation which is honored and respected by other nations. Hence, education is an ongoing endeavor to produce excellent human capital in physical, emotional, spiritual, intellectual, and social forms (Ministry of Education (Malaysia (MOE), 2015). The community entrusts the role of teachers in the development of this targeted human capital. Thus, the direct teaching and facilitating (T\&L) of teachers is the most crucial input in shaping the students' outcomes. Teacher preparation is essential when planning appropriate methods and techniques for a lesson subject. Teachers should be creative in delivering knowledge as students in a class have diverse intellects, characters, and backgrounds. One of the exciting strategies to be incorporated in teaching and learning sessions is the gamification method which is gamebased learning.

Gamification is gamed-based learning that has mostly been used in the learning process in the 21 st century. It is an activity that employs games with mechanical elements to provide practical solutions by attracting individual population groups (Prambayun, 2015). Sebastian, Dan, Rilla, and Lennart (2011) observe that gamification uses games with design elements in non-game contexts. A gamification approach that uses game elements can stimulate and inspire its practitioners to incorporate teaching into games in education (Sayed Yusof, Wee Hoe, \& Muhammad Zaffwan, 2014). Such an approach can instill an innovative culture in teaching that makes it more interactive. At the same time, it can boost national education quality through the teaching and learning process (PdP). The selection of teaching methods should be in line with the development of technology today. Gamification in education is a breath of fresh air that benefits both educators and students and complements teaching methods in accomplishing teaching and educational objectives (Nurfazliah, Jamalludin, Shaharuddin, \& Megat Aman Zahiri, 2015).

The United Kingdom's 2014 Global Gaming Statistics record that 74 per cent of K-8 educators adopt digital games to facilitate the learning process, and 33 per cent apply the game to assess students' skills knowledge levels, while 29 per cent officially perform a formative assessment of students' fundamental skills and knowledge. Teachers use games to teach young people, and 56 per cent of parents believe that the games used in learning have positively impacted their children (Rohaila \& Khalid, 2017). In Malaysia, MOEtargets students who are driven by thought skills. These thinking skills should enable every student to learn how to acquire knowledge throughout their lives by instilling a lifelong learning experience to link different knowledge disciplines and develop new knowledge. Each student should master various cognitive skills, including reasoning and critical thinking, both creative and innovative. This skill area is less visible, making it less possible for students to apply knowledge and think critically beyond the academic context.

As preparation to be prospective Geography teachers at the Universiti Pendidikan Sultan Idris (UPSI), students are exposed to various teaching and learning-related courses such as Teaching, Technology, and Assessment 1, and Teaching, Technology, and Assessment 2 in the fifth and sixth semesters respectively, before they can undergo teacher training at school. Such courses explain the theoretical aspects and pedagogical practices with simulated teaching and learning sessions, which include the gamification approach. Still, there is a lack of implementation of the gamification approach in assessing the teaching process during a macro teaching session. Therefore, this study examines the 
readiness among trainee Geography teachers at UPSI to use the game-based gamification approach. The main variables examined in the study were the gamification knowledge of trainee teachers, their skills, and the use of the gamification approach. The study objectives are as follows: (i) to identify the level of knowledge, skills, and the usage of the gamification approach among trainee Geography teachers at UPSI and (ii) to analyze the relationship between the knowledge, skills, and the usage of the gamification approach among trainee Geography teachers at UPSI.

Theoretical Framework Gamification Approach in the Teaching and Learning Process

\section{The Definitions of Gamification}

Education is the gateway to future generation formation. Education means efficient teaching and learning methods through which this process takes place between students and teachers. The teaching and learning process is a diagnostic and prescriptive one, in which students can make a permanent change through participation in the learning experience.

Gamification is a tool for incorporating game design elements in non-game contexts (Heintzman, 2020; Kurnia \& Sudirman, 2013). It uses features with game characteristics for activities not linked to the game (Pramana, 2015). Pramana also points out that the gamification method makes technology more appealing by stimulating the interest of affected users, through them helping to solve problems and building human psychological tendencies towards more exciting activities.

Moreover, Rohwati (2012) has conducted a study on the use of educational games for Biology which conceptualized the classification of living beings and found that the students were more relaxed in attaining achievements and which helped to create a vital mastery of subjects. Meanwhile, a study conducted by Farozi (2016) has used games to learn about the preparation of a library application. His research showed that the preparation of the library application was easier to understand and master.

Prasetyo (2016) applied the game concept to planning Al-Quran learning applications. Prasetyo discovered that this technique could help to surmount one of Quran's learning problems. This study on the gamification method approach among trainee Geography teachers was supported by findings obtained from the previous three studies on the use of game methods in teaching and learning.

\section{Knowledge of Gamification Approach}

Based on previous research studies, knowledge is defined as the acquisition, retention, and use of information; in other words, it is a combination of understanding, experience, intelligence, and skill. This mastery of knowledge necessitates two essential foundations that complement each other: the first one is the concept of an object that is thought to be global and requires the ability to think. The second concept is derived from an impression that requires a sense of resistance depending on how different ideas are acquired: perception or impression, imagination, memory, judgement, and abstract concepts and considerations (Sebastian, Dan, Rilla \& Lennart, 2011).

Knowledge is also defined as the level of awareness of truth, principles, and information. It focusses on past experience and longstanding experience and is used to accomplish unprecedented goals (Azhar et al., 2004). Knowledge exists either from oneself or from other sources used to achieve unrealized objectives. According to Azilah 
and Zarina (1997), knowledgeable teachers must attain the same level or surpass general knowledge to implement gamification in daily tasks. Therefore, this study identifies the knowledge level of the gamification approach among trainee Geography teachers.

\section{The Importance of Gamification in Education}

Gamification has many benefits that can help to enhance the learning process for students at all academic levels. Incorporating gamification in the learning process enables students to enjoy the experience and overcome the challenges of academic education (Ong et al., 2013). Gamification involves a variety of emotions, starting with feeling curious, puzzled, and frustrated to feeling contented when the game is completed successfully (Pramana, 2016). Such an approach helps students to continuously pursue knowledge in order to satisfy their curiosity and obtain self-satisfaction. Cankaya and Karamete (2009) emphasize that students enjoy learning by playing and having fun. Playing gives them the chance to make mistakes several times; in other words, to learn from the experience of making mistakes without having to feel the tension. Hence, making mistakes repeatedly is viewed as one way of learning. Students may begin to see failure as an opportunity to remain competitive through gamification, rather than an excuse to give up (McGrath \& Bayerlein, 2013).

Using the gamification method indirectly enhances learning knowledge by developing cognitive skills and improves teachers' skills. From a cognitive standpoint, gamification provides students with the experience of undergoing the process of mastery and engages them in difficult situations (Kiili, 2014) as well as offering several alternatives to the complete process. Hence, a new perspective on learning can be created to help students understand and recognise their potential. As a result, this article will elaborate on and investigate the use of gamification in teacher training and learning sessions among geography teacher trainees..

\section{Methods}

\section{Research Design}

This study focuses on quantitative research surveys, using systematic methods to gather specific information from a specific population.).

\section{Population and Sampling}

The researcher conducted this study at Universiti Pendidikan Sultan Idris (UPSI) in Tanjong Malim, Perak. The study population consisted of students taking Geography classes during their sixth and seventh semesters in UPSI. The sample consisted of 52 students taking Geography classes in the sixth and seventh semesters from the same population group with 121 students in the seventh semester also taking part. Students were selected who attended Geography classes and underwent training for eight weeks. The total number of students was 173. Based on the Krejcie and Morgan (1970) sample schedules, the samples were collected from 86 students consisting of 43 male students and 43 female students from the total number in the sixth and seventh semesters, who were selected by simple random sampling.

\section{Study Instrument}

The information collection technique used in the study was using a questionnaire. The questionnaire was distributed via the online survey platform 'Google form,' which takes no more than 15 minutes to complete. The development of the items was based on the 
study's two main independent variables: namely gamification knowledge and gamification skill with the dependent variable being the usage of gamification (Figure 1). The study questionnaires were self-reported except for knowledge variables. There were items cited and modified from previous source-specific research. The process of content validity confirmation by subject matter experts and face validity had also been carefully carried out.

This set of questionnaires consisted of five parts. Part A consisted of five items related to the respondent's profile, semester, gender, race, and parents' highest educational level. Part B was the gamification knowledge variable and consisted of 10 items developed through reference to the studies conducted by Siti Noraida (2017), and Cankaya and Karamate (2009). Part C was the gamification skill variable consisting of 12 items. The scale of measurements used was a five-point Likert scale for 'knowledge' and 'skill' variables. Each item was scored on a 1 to 5 scale, where $1=$ Strongly disagree, $2=$ Disagree, $3=$ Agree Less, $4=$ Agree, and $5=$ Strongly Agree. Next, Part D was the usage of the gamification variables consisting of 10 items. Items were constructed by the reviewer following the context of the study. The scale of measurements used was a fivepoint Likert scale for the 'usage' variable. Each item was scored on a 1 to 5 scale, where 1 = Never, $2=$ Rarely, $3=$ Occasionally, $4=$ Often, and $5=$ Very Often. A pilot study was conducted on 30 respondents who were not from the study sample. The pilot study aimed to determine the study instrument's reliability and examine the study variables' consistency. The revised reliability value (Cronbach's Alpha) for all pilot study items exceeded 0.7 (Table 1). A value of 0.7 or higher implies an acceptable internal consistency (Adams \& Lawrence, 2015).

Table 1

Cronbach's Alpha value for each pilot study variable

\begin{tabular}{clcc}
\hline Part & \multicolumn{1}{c}{ variable } & $\begin{array}{c}\text { No. of } \\
\text { Item }\end{array}$ & Cronbach Alpha Value \\
\hline B & Gamification Knowledge & 10 & 0.77 \\
C & Gamification Skill & 12 & 0.96 \\
D & Usage of the Gamification & $1-10$ & 0.98 \\
\hline
\end{tabular}

This article's discussion section aimed to identify the three main focus variables: the level of knowledge, skill, and the usage of the gamification approach among trainee Geography teachers. Table 2 shows the three levels used in the discussion of the findings.

Table 2

Cut-Off Point Level for every study variable (Best, 1977)

\begin{tabular}{cc}
\hline Scale & Level \\
\hline Score $1.00-2.33$ & Low \\
Score $2.34-3.66$ & Medium \\
Score $3.67-5.00$ & High \\
\hline
\end{tabular}

Moreover, this study analysed the differences in knowledge, skill, and usage according to gender among trainee Geography teachers. A t-test was used to analyse the differences by gender for each variable. The study also examined the relationship between knowledge, skill, and the usage of the gamification approach among trainee Geography teachers. Pearson correlation analysis was used in this study to assess the relationship of each variable. It could directly measure the size of the effect of whether the correlation 
was positive or negative. A linear relationship was measured with the Pearson correlation coefficient $(r)$ at the level<0.05. The correlation coefficient consisted of two elements: the value of the coefficient and the sign of the coefficient. The value of correlation coefficient (r) was between -1 to $1(-1<\mathrm{r}<1)$.

\section{Findings}

\section{Respondents' Profile}

Table 3 summarizes the result of the analysis of the respondents' profile. A total of 86 students from the sixth and seventh semesters of the Bachelor of Education (Geography) program participated in the study. Twenty-four students $(27.9 \%)$ were in the sixth semester, while 62 students $(72.1 \%)$ who underwent teacher training were in the seventh semester. Next, the respondents consisted of 43 males (50\%) and 43 females (50\%). Table 3 also shows that 63 students $(73.3 \%)$ were Malays and 12 students (14\%) were the natives of Sarawak. Precisely ten students $(11.6 \%)$ were the natives of Sabah, while only one student $(1.2 \%)$ was Chinese.

Table 3

Frequency Distribution of Respondents' Profile

\begin{tabular}{llll}
\hline Respondents' Profile & & Frequency & $\begin{array}{l}\text { Percentage } \\
(\%)\end{array}$ \\
\hline Semester & Six & 24 & 27.9 \\
& Seven & 62 & 72.1 \\
\multirow{3}{*}{ Gender } & Total & 86 & 100 \\
& Male & 43 & 50.0 \\
\multirow{2}{*}{ Race } & Female & 43 & 50.0 \\
& Total & 86 & 100 \\
& Malay & 63 & 73.2 \\
& Chinese & 1 & 1.2 \\
& Sarawak's Bumiputera & 12 & 14.0 \\
& Sabah's Bumiputera & 10 & 11.6 \\
& Total & 86 & 100 \\
\hline
\end{tabular}

\section{Levels of Knowledge, Skill, and the Usage of the Gamification Approach among Trainee Geography Teachers}

The cut-off point value specified in Table 3 was used to respond to the first study's objective, namely, to identify the level of knowledge, skill, and the usage of the gamification approach among trainee Geography teachers at UPSI. The findings shown in Table 4 for all three variables, specifically knowledge, skill, and the usage of the gamification approach showed that 76 trainee teachers $(88.4 \%)$ had a high level of knowledge of the gamification approach. In comparison, the remaining ten trainee teachers $(11.6 \%)$ had a moderate level of knowledge of the gamification approach. The analysis showed that the average level of knowledge of the gamification approach was high $(\mathrm{M}=4.08, \mathrm{SP}=0.46)$. It implied that most trainee Geography teachers knew the gamification approach's meaning and characteristics applied during (T\&L). The findings conducted by Azilah and Zarina (1997), and Jamilah et al. (2011) were consistent with 
the study findings. Teachers had to achieve the same level or surpass a general knowledge of the gamification method and competence in order to apply gamification in daily tasks.

The skill level for the gamification approach showed that $69(80.2 \%)$ trainee teachers were at a high level, while the remaining 17 trainee teachers $(19.8 \%)$ were at a moderate level. The analysis indicated that the average skill level relating to the gamification approach was at a high level $(\mathrm{M}=4.13, \mathrm{SP}=0.47)$. It showed that most trainee Geography teachers were competent in using the gamification approach, such as Kahoot and Plickers applications, to assess students' understanding. This statement was consistent with the findings of Abdullah and Ainon (1999) confirming that the use of technology in education in Malaysia was one of the efforts to improve skills. However, the study findings were not in accordance with the study of Noriah et al. (2002) who concluded that teachers were not competent to use technology and were still practicing the 'chalk and talk' method.

Finally, the outcome of the level of gamification usage indicated that $57(66.3 \%)$ trainee teachers were at a high level, followed by 23 trainee teachers $(26.7 \%)$ who were at a moderate level. Meanwhile, six trainee teachers $(7.0 \%)$ were at a lower level. The analysis showed that the average level of the usage of the gamification approach was at a high level $(\mathrm{M}=3.82, \mathrm{SP}=0.84)$. It showed that the level of the usage of the gamification approach was at good and satisfactory levels. The findings were not consistent with Rohwati's (2012) study, which explained that technology had been established in education for a long time, but most teachers still practiced conventional (T\&L) delivery methods and did not emphasise thinking skills in the daily (T\&L).

Table 4

Levels of Knowledge, Skill, and the Usage of the Gamification Approach

\begin{tabular}{|c|c|c|c|c|c|c|c|c|c|}
\hline \multirow[t]{2}{*}{ Variable } & \multicolumn{2}{|c|}{ Low Level } & \multicolumn{2}{|c|}{$\begin{array}{c}\text { Medium } \\
\text { Level }\end{array}$} & \multicolumn{2}{|c|}{ High Level } & \multirow[t]{2}{*}{ Mean } & \multirow[t]{2}{*}{$\begin{array}{c}\text { Standard } \\
\text { Deviation }\end{array}$} & \multirow[t]{2}{*}{$\begin{array}{l}\text { Mean } \\
\text { Level }\end{array}$} \\
\hline & $\mathrm{N}$ & $\%$ & $\mathrm{~N}$ & $\%$ & $\mathrm{~N}$ & $\%$ & & & \\
\hline Knowledge & 0 & 0.0 & 10 & 11.6 & 76 & 88.4 & 4.08 & 0.46 & High \\
\hline Skill & 0 & 0.0 & 17 & 19.8 & 69 & 80.2 & 4.13 & 0.47 & High \\
\hline Usage & 6 & 7.0 & 23 & 26.7 & 57 & 66.3 & 3.82 & 0.84 & High \\
\hline
\end{tabular}

\section{Descriptive Analysis of Variables: Knowledge, Skill, and the Usage of the Gamification}

The descriptive data analysis of the variables used in this study were three main variables of knowledge, skill, and the usage of the gamification approach among trainee Geography teachers. The aim was to measure the scale of agreement of items for each variable. The findings of the analysis were shown in the form of diagrams. Figure 1 displays descriptive analysis findings for knowledge of the gamification approach among trainee Geography teachers at UPSI.

Approximately 46 respondents (53.5\%) responded 'Strongly Agree' to the first item, which was 'The gamification approach is a mechanical game element to provide practical solutions by attracting specific cluster interest.' This result was followed by 38 respondents $(44.2 \%)$ who responded 'Agree' to the first item. Next, 44 respondents (51.2\%) answered 'Agree' to the second item which was 'The gamification approach is a method used to solve a problem of how to think while playing.' This was followed by 38 respondents (44.2\%) who answered: 'Strongly Agree'. 
The third item was 'Gamification approach has two elements, namely self-elements and social elements.' About 47 respondents (54.7\%) answered 'Agree' to this statement, followed by 33 respondents (38.4\%) who answered, 'Strongly Agree'. Next, a total of 43 respondents $(50.0 \%)$ reacted with the response 'Strongly Agree' to the fourth item that was 'The gamification approach can be used either online or for the modernization of traditional games.' This was followed by 42 respondents $(48.8 \%)$ who responded: 'Agree'. Subsequently, about 49 respondents (57.0\%) responded 'Agree' for the fifth item that was 'The gamification approach can be used as an option or as complementary to teaching methods to accomplish goals.' Thirty-five respondents $(40.7 \%)$ reacted 'Strongly Agree' to this statement.

Next, the sixth item was 'The gamification approach can be carried out either inside or outside the classroom.' Overall, 49 respondents (57.0\%) answered: 'Strongly Agree'. This was followed by 31 respondents $(36.0 \%)$ who chose 'Agree.' Then, 45 respondents (52.3\%) answered 'Strongly Agree' to the seventh item, which was 'Do you have knowledge about online gamification apps such as Kahoot and Socrative?' In contrast, only three respondents (3.5\%) responded: 'Less Agree'.

Subsequently, a total of 45 people (52.3\%) answered 'Agree' to the eighth item that was 'A modernized traditional gamification approach such as musical chair games and Teng-Teng or Ketingting.' This was followed by 36 respondents $(41.9 \%)$ responding: 'Strongly Agree'. Next, 25 respondents (29.1\%) answered 'Disagree' to the ninth item that was 'The gamification approach is only to be carried out in the classroom.' This was followed by 21 respondents (24.4\%) who chose 'Strongly Disagree'. Finally, 26 respondents $(30.2 \%)$ responded 'Strongly Disagree' to the tenth item that was 'The gamification approach is only available online.' 21 respondents $(24.4 \%)$ answered: 'Disagree'.

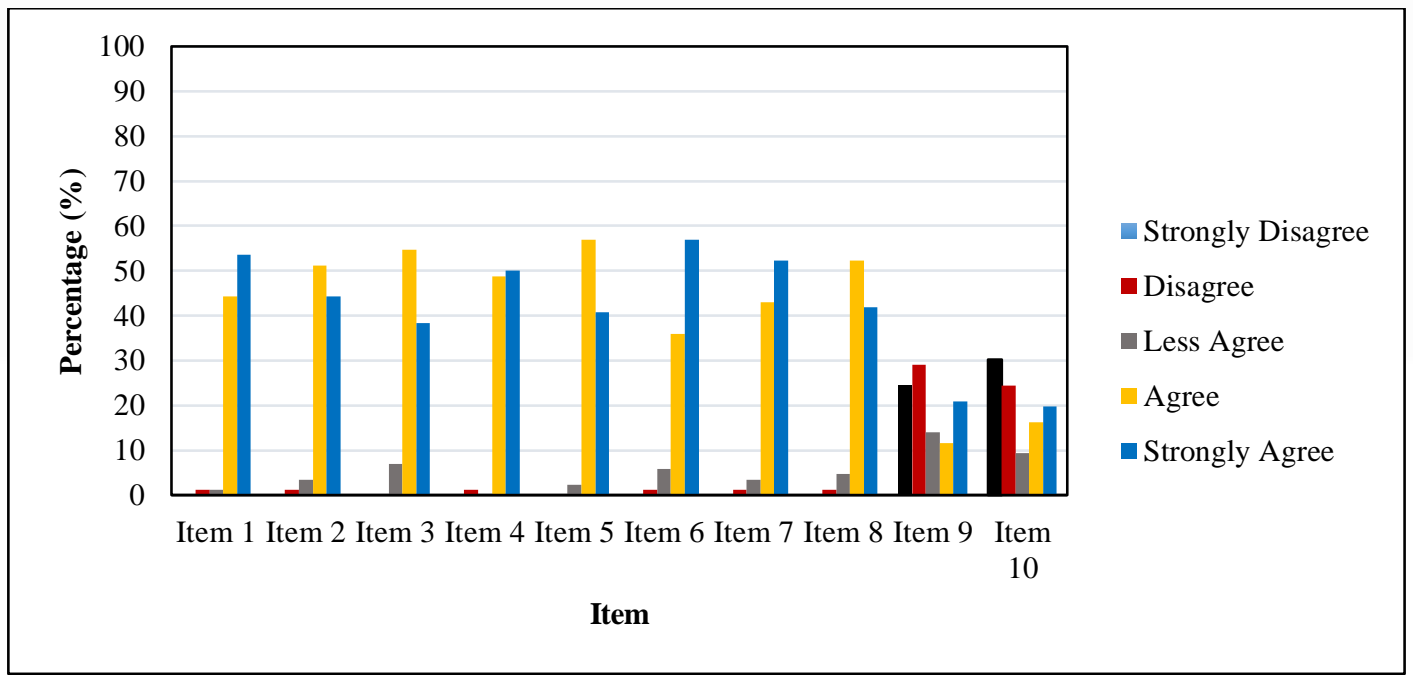

Figure 1. Knowledge of the Gamification Approach.

The second descriptive analysis was the gamification skill variable of UPSI trainee Geography teachers. Figure 2 illustrates descriptive analysis findings for the gamification approach skill among trainee Geography teachers at UPSI. About 41 respondents $(47.7 \%)$ answered 'Strongly Agree' to the first item, which was 'I am competent using online gamification approaches such as Kahoot, Padlet, and Plickers.' This was followed by 35 who responded (40.7\%): 'Agree'. Precisely 41 respondents (47.7\%) answered 'Agree' to 
the second item which was 'I am skilled using a modernised traditional gamification approach such as musical chair games.' However, nine respondents $(10.5 \%)$ responded: 'Less Agree'.

Next, precisely 39 respondents $(45.3 \%)$ replied 'Agree' to the third item that was 'I am competent in the use of the gamification approach.' This was followed by 35 respondents (40.7\%) who answered: 'Strongly Agree'. However, precisely 35 respondents (40.7\%) responded 'Agree' to the fourth item which was 'I am skilled at creating new gamification.' About 28 respondents (32.6\%) chose 'Less Agree.' Then, precisely 44 respondents (51.2\%) answered 'Agree' to the fifth item which was 'I am proficient in applying the elements of the gamification approach such as self-elements and social elements to students.' This was followed by 33 respondents $(38.4 \%)$ who responded: 'Strongly Agree'.

Subsequently, precisely 34 respondents (39.5\%) answered 'Agree' to the sixth item that was 'I am more competent managing classes using a gamification approach.' In comparison, only nine respondents $(10.5 \%)$ chose 'Less Agree'. Precisely 31 respondents $(36.0 \%)$ answered 'Agree' to the seventh item that was 'I experience difficulties in employing a gamification approach in class.' This was followed by 20 respondents (23.3\%) who responded: 'Disagree'. Precisely 50 respondents $(58.1 \%)$ answered 'Agree' to the eighth item that was, 'I can improve students' thinking skills using a gamification approach.' In contrast, only eleven respondents (12.8\%) chose 'Less Agree'.

Next, precisely 41 respondents (47.7\%) answered 'Agree' to the ninth item that was 'I manage to improve students' performance by using a gamification approach.' In comparison, only five respondents (5.8\%) chose 'Less Agree'. Then, about 52 respondents $(60.5 \%)$ responded 'Agree' to the tenth item that was 'I can keep students' interest in lessons through a gamification approach.' However, only six respondents (7.0\%) chose 'Less Agree'. About 48 respondents (55.8\%) answered 'Agree' to the eleventh item that was 'I am proficient using gamification applications such as Kahoot and Plickers to assess students' understanding.' In contrast, only three respondents $(3.5 \%)$ chose 'Less Agree'. Finally, precisely 52 respondents (60.5\%) responded 'Agree' to the twelfth item that was 'I am competent using the gamification approach to measure the achievement of learning objectives.' However, only three respondents $(3.5 \%)$ chose 'Less Agree', and one respondent (1.2\%) answered, 'Disagree'.

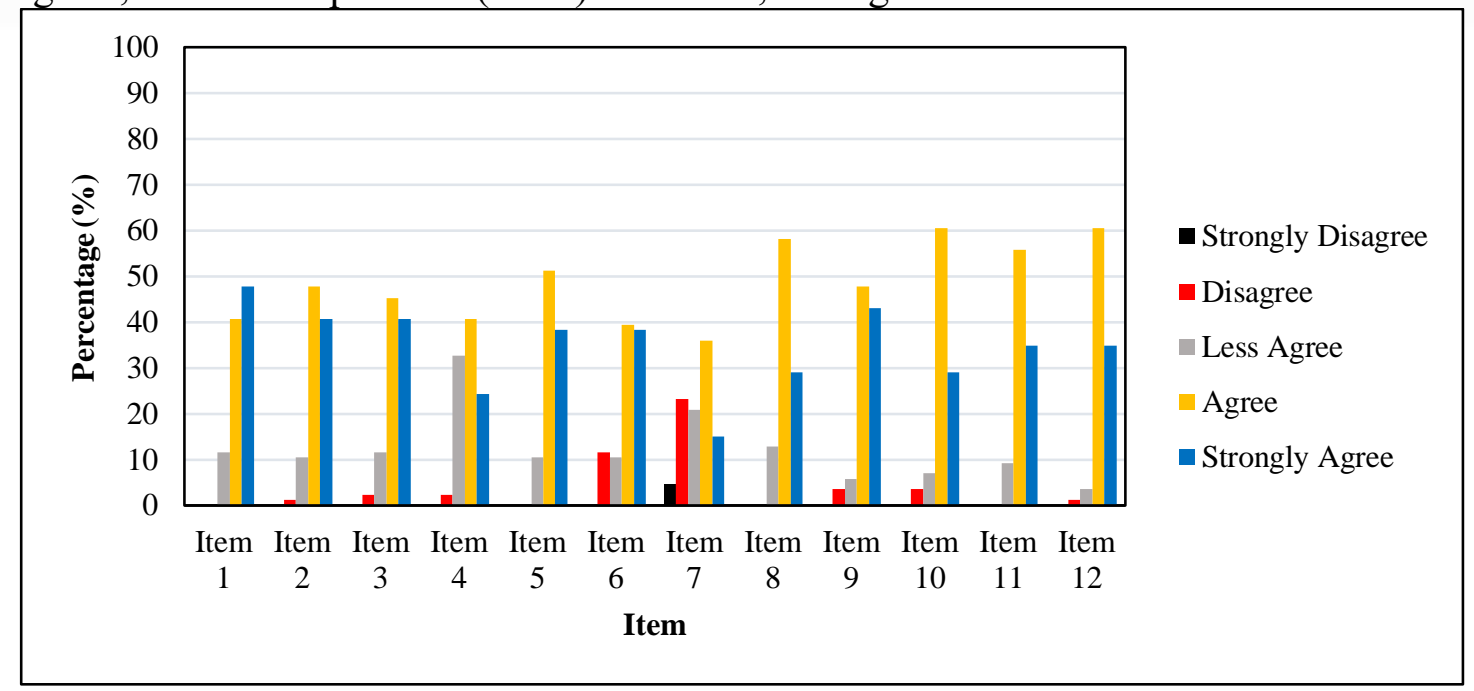


Figure 2. The Skill of the Gamification Approach.

Figure 3 depicts descriptive analysis findings for the usage of the gamification approach among trainee Geography teachers at UPSI. Precisely 44 respondents $(51.2 \%)$ answered 'Often' to the first item that was 'I use an online gamification approach.' This was followed by 21 respondents $(24.4 \%)$ who responded: 'Very Often'. Overall, 45 respondents (52.3\%) answered 'Often' to the second item that was 'I use a traditional modernized gamification approach such as Poison Ball.' In comparison, ten respondents (11.6\%) responded: 'Occasionally'. Next, precisely 37 respondents $(43.0 \%)$ answered 'Often' to the third item that was 'I use a gamification approach such as Padlet as an interactive board between instructors.' This was followed by 19 respondents $(22.1 \%)$ who responded: 'Very Often'. Meanwhile, about 18 respondents (20.9\%) answered 'Occasionally'. However, approximately six respondents (7.0\%) responded 'Rarely' and 'Never' respectively.

A total of 35 respondents $(40.7 \%)$ answered 'Often' to the fourth item that was 'I use a gamification approach such as Quizziz to stimulate interest during the (T\&L) process.' This was followed by 22 respondents $(25.6 \%)$ who chose 'Very Often'. Next, precisely 37 respondents $(43.0 \%)$ answered 'Often' to the fifth item that was 'I use a gamification approach such as musical chair games to assess students' understanding.' This was followed by 29 respondents (33.7\%) who responded: 'Very Often'. Then, 47 respondents (5.7\%) chose 'Often' for the sixth item that was 'I use a gamification approach such as Kahoot as a learning quiz.' This was followed by 24 respondents $(27.9 \%)$ who answered: 'Very Often'.

Subsequently, 32 respondents $(37.2 \%)$ answered 'Often' to the seventh item that was 'I confront difficulties to use a gamification approach such as Smartboard as a teaching aid tool.' This was followed by 26 respondents $(30.2 \%)$ who responded: 'Very Often'. Next, 22 respondents $(25.6 \%)$ answered 'Often' to the eighth item that was 'I use a gamification approach such as Wallwisher as an interactive board between instructors and students.' This was followed by 26 respondents (30.2\%) who responded 'Occasionally', while 20 respondents $(23.3 \%)$ chose 'Very Often'.

About 35 respondents $(40.7 \%)$ answered 'Often' to the ninth item that was 'I use a gamification approach such as Plickers to assess students' understanding.' In comparison, 16 respondents $(18.6 \%)$ responded 'Occasionally'. Finally, 32 respondents $(37.2 \%)$ answered 'Often' to the last item that was 'I use a gamification approach such as Socrative as a learning quiz.' This was followed by 27 respondents $(31.4 \%)$ who responded 'Very Often'. The respondents' responses showed a positive attitude to developing the gamification approach, thus aligning with the 21st Century Learning (PAK-21) recommended by MOE to produce first-class human capital (Ministry of Education, 2016). 
Mahat, H., et al. (2021). The readiness of geography teacher trainees in gamification approach.....

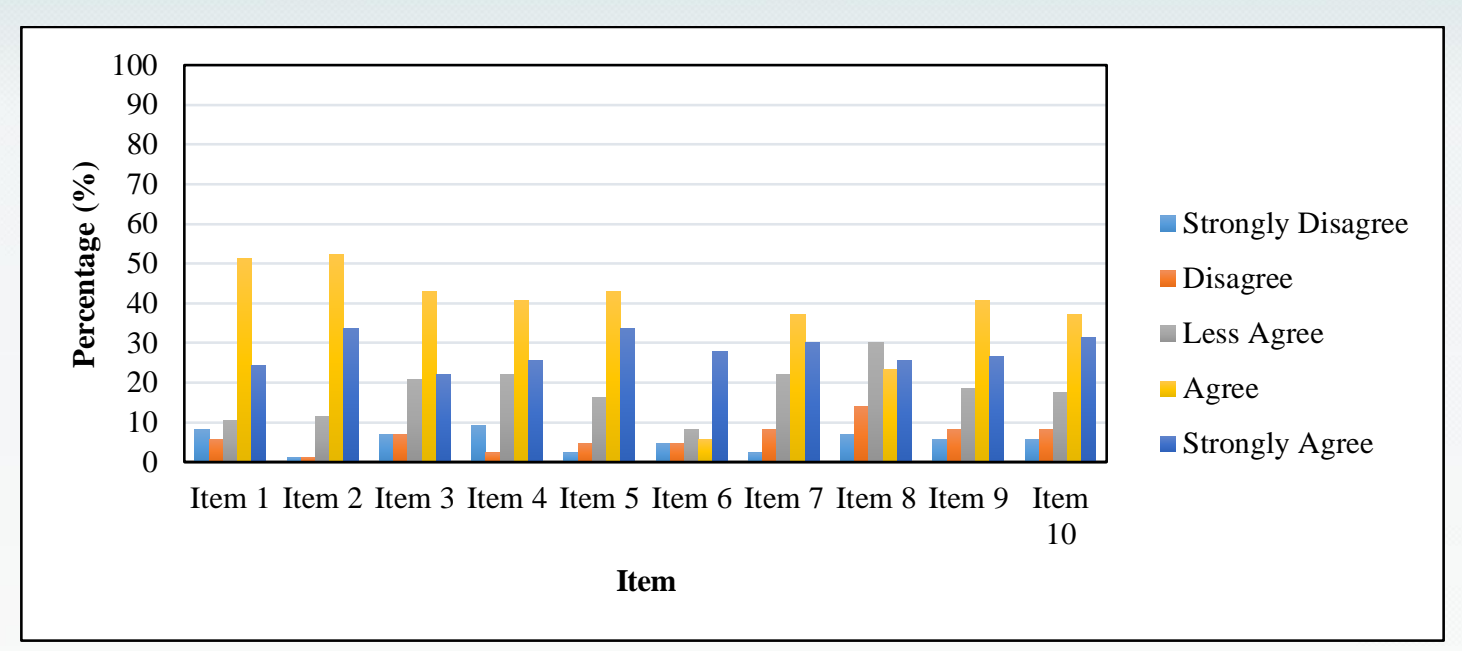

Figure 3. The Usage of the Gamification Approach.

Analysis of the Relationship between Knowledge, Skill, and the Usage of the Gamification Approach

The analysis of the relationship between knowledge, skill, and the usage of the inferential gamification approach was made by using the Pearson correlation coefficient analysis to measure the strength or magnitude and respond to the second objective of the study. In the analysis, the constructed hypotheses are as follows:

Ho(1): There is no relationship between knowledge and gamification approach skill among trainee teachers.

Ho(2): There is no relationship between knowledge and the usage of the gamification approach among trainee teachers.

Ho(3): There is no relationship between skill and the usage of the gamification approach among trainee teachers.

Table 5 shows the study results related to the relationship between the knowledge and skill of the gamification approach. Correlation results indicated a moderate positive correlation between knowledge and gamification approach skill among trainee Geography teachers at UPSI. The value of this correlation was $r=0.385$, with $p=0.000$ $(\mathrm{p}<0.01)$. Therefore, there was a significant relationship between knowledge and the gamification approach skill. Based on the Pearson correlation analysis results, the researcher decided to reject the first null hypothesis, $\operatorname{Ho}(1)$, that 'There is no relationship between knowledge and gamification approach skill among trainee teachers.' It implied that the higher the level of knowledge, the greater the gamification approach skill among trainee teachers. The findings were consistent with those of the studies conducted by Azilah et al. (1997), Cankaya and Karamete (2009), and Farozi (2016), where there was a relationship between teachers' knowledge of gamification. Teachers had to achieve the same level or surpass general knowledge and could apply gamification in daily tasks.

Table 5 also illustrates the study results related to the relationship between knowledge and the usage of the gamification approach. The correlational analysis results showed a moderate positive correlation between knowledge and the usage of the gamification approach among trainee Geography teachers at UPSI. The correlation value was $r=0.329$, with $\mathrm{p}=0.002(\mathrm{p}<0.01)$. It implied that there was a significant relationship between knowledge and the usage of a gamification approach. Based on the Pearson correlation 
analysis results, the researcher decided to reject the second null hypothesis, $\operatorname{Ho}(2)$, which was 'There is no relationship between knowledge and the usage of the gamification approach among trainee teachers.' It suggested that the higher the level of knowledge, the greater the usage of the gamification approach among trainee teachers. Such a statement was consistent with Pramana (2015) and Rohwati's (2012) studies that described the usage of the gamification method to indirectly enhance learning knowledge in the development of cognitive skills that further improved the teachers' skills.

Finally, Table 5 depicts the study results related to the relationship between skill and the usage of the gamification approach. Correlational analysis results showed a strong positive correlation between skill and the usage of the gamification approach among trainee Geography teachers at UPSI. The correlation value was $r=0.670$, with $p=0.000$ $(p<0.01)$. It signified that there was a significant relationship between skill and the usage of the gamification approach. Based on the Pearson correlation analysis results, the researcher decided to reject the third null hypothesis, $\operatorname{Ho}(3)$, which was 'There is no relationship between skill and the usage of the gamification approach among trainee teachers.' It inferred that the higher the level of skill, the greater the usage of gamification approach among trainee teachers. These findings were consistent with the studies of Kiili et al. (2014), Prambayun (2016), and Cugelman (2013), which highlighted the usage of gamification technique which indirectly enhanced learning knowledge in the development of cognitive skills that further improved the teachers' skills.

Table 5

Approach Analysis of Relationship between Knowledge, Skill, and the Usage of the Gamification Approach

\begin{tabular}{lcccc}
\hline Variable & \multicolumn{2}{c}{ Skill } & \multicolumn{2}{c}{ Usage } \\
& $\mathrm{r}$ & $\mathrm{p}$ & $\mathrm{r}$ & $\mathrm{p}$ \\
\hline Knowledge & $0.385^{* *}$ & 0.000 & $0.329^{* *}$ & 0.002 \\
Skill & & & $0.670^{* *}$ & 0.000 \\
\hline
\end{tabular}

$\mathrm{r}=$ Pearson Correlation, $\mathrm{p}=$ significant

*significant correlation at $\mathrm{r}<0.01$.

\section{Conclusion}

As those who implement the gamification approach, trainee teachers need to ensure that their knowledge, skill, and usage align with the PAK-21 recommended by the MOE to produce first-class human capital. Trainee teachers can utilize a range of approaches during (T\&L) sessions as a preparation to become educators in the future. It is evident from the study's overall results that trainee Geography teachers have substantial knowledge of the gamification approach in Geography and are implementing various gamification methods during the $(\mathrm{T} \& \mathrm{~L})$ session. It also proves that if the gamification approach is correctly applied, it may attract students to focus on the Geography (T\&L) session. This would indirectly impact the enhancement of knowledge, skill, and the usage of gamification method among trainee Geography teachers. The university should take 
proactive steps by promoting the usage of a gamification approach in lectures and providing the facilities needed by trainee teachers while on campus.

\section{References}

Abdullah, H. \& Ainon.M. (1999). Kemahiran interpersonal untuk guru bestari. Kuala Lumpur: Utusan Publication. (In Malay)

Abdul Rashid, M \& Zurida, I. (2001). Pengalaman belajar-mengajar guru-guru pelatih Universiti Sains Malaysia. Jurnal Pendidik dan Pendidikan, 7, 41-56.

Adams, K. A. \& Lawrence, E. K. (2015). Research methods, statistics and application. London: SAGE.

Ahmad Mahdzan Ayob. (2007). Kaedah penyelidikan sosioekonomi $\left(3^{\text {rd }}\right.$ ed.). Kuala Lumpur: Dewan Bahasa dan Pustaka.

Azilah N. \& Zarina. 1997. Persepsi guru dalam perkhidmatan mengenai penggunaan komputer. Prosiding dari Persatuan Teknologi Pendidikan Malaysia $10^{\text {th }}$ Konvensyen. Serdang: Universiti Putra Malaysia. 21-23 Mei.

Azhar, A. H., Adanan, M. J., Ishak, M. S., \& Mohd Koharuddin, M. B. (2004). Pembelajaran arahan kendiri dan hubungannya dengan kefahaman terhadap E-pembelajaran: Satu kajian di kalangan staf akademik Universiti Teknologi Malaysia. Johor: Universiti Teknologi Malaysia. Retrieved from http://onlinelibrary.wiley.com/doi/10.1002/cbdv.200490137/abstract.

Best, J.W. (1977). Research in education. New Jersey: Prentice Hall.

Cankaya, S., \& Karamete, A. (2009). The effects of educational computer games on student's attitudes toward mathematics course and educational computer games. Procedia-Social and Behavioural Sciences, 1(1), 145-149.

Cugelman, B. (2013). Gamification: What it is and why it matters to digital health behaviour change developers, Serious Games, 1(1), 1-6.

Farozi, M. (2016). Rancang bangun website gamifikasi sebagai strategi pembelajaran dan evaluasi hasil belajar mahasiswa. Seminar Nasional Teknologi Informasi dan Multimedia, STMIK Universitas AMIKOM, Yogyakarta, 6-7 Februari, Universitas AMIKOM, Jogjakarta.

Heintzman, R. (2020). Interactive Geovisualizations (iGEO): A New Approach to Teaching and Learning Physical Geography. Review of International Geographical Education (RIGEO), 10(4), 664-683.

Higgins, S., Mercier, E., Burd, L., \& Joyce-Gibbons, A. (2012). Multi-touch tables and collaborative learning. British Journal of Educational Technology, 43(6), 1041-1054.

Jamilah, H. A., Hasrina, M., Hamidah, A., \& Juliana, A. E. (2011). Pengetahuan, sikap dan amalan masyarakat Malaysia terhadap isu alam sekitar. Akademika, 81(3), 103-115.

Kementerian Pendidikan Malaysia. 2015. Pelan Pembangunan Pendidikan Malaysia 2015-2025 (Pendidikan prasekolah hingga lepas menengah). Putrajaya: Kementerian Pendidikan Malaysia.

Kementerian Pendidikan Malaysia. (2016). Kurikulum Standard Sekolah Menengah Geografi: Dokumen standard kurikulum dan pentaksiran. Putrajaya: Kementerian Pendidikan Malaysia.

Kiili, K., Ketamo, H., Kickmeier-rust, M. D. (2014). Eye tracking in games-based learning research and game design. International Journal of Serious Games, 1(2), 51-65. 
Kurnia, E. \& Z. Sudirman, D.M.T.I. (2013). Lab ware: implementational of gamification approach in computer Lab activities. International conference on information system for business competitiveness, Universitas Multimedia Nusantara, 1 December 2019.

Krejcie, R.V. \& Morgan, D.W. (1970). Determining sample saiz for research activities. Educational and Psychological Measurement, 30(3), 607-610.

McGrath, N., \& Bayerlein, L. (2013). Engaging online students through the gamification of learning materials: The present and the future. 30th ascilite Conference 2013 Proceedings 573-577.

Retrieved

from https://www.ascilite.org/conferences/sydney13/program/papers/McGrath.pdf

Noriah, I., Siti Rahayah, A., Rosseni, D. \& Aidah, A. K. (2002), Expanding traditional classroon through computer technology: A collaborative learning process. Jurnal Teknologi, 3(2), 210-222.

Nurfazliah, M., Jamalludin, H., Shaharuddin, M. S., \& Megat Aman Zahiri, M. Z. (2015). Penggunaan game-based learning bagi meningkatkan kemahiran penyelesaian masalah kreatif dalam Matematik. 2nd International Education Postgraduate Seminar (IEPS 2015).

Ong, D. L. T., Chan, Y. Y., Cho, W. H., \& Koh, T. Y. (2013). Motivation of learning: An assessment of the practicality and effectiveness of gamification within a tertiary education system in Malaysia. World Academy of Researchers, Educators, and Scholars in Business, Social Sciences, Humanities and Education (In association with the Academy of World Finance, Banking, Management and IT) Conference Proceedings, 1(1), 131-146.

Pramana, D. (2015). Perancangan pengetahuan aplikasi dengan konsep gamifikasi. Jurnal Sistem dan Informatika, 10(2), 25-56.

Prambayun, A. 2015. Pola perancangan gamifikasi untuk membangun engagement siswa dalam belajar. Seminar Nasional Teknologi Informasi dan Multimedia, Yogjakarta, 2302-3805.

Prasetyo, I.A., Destya, S. \& Rizky. (2016). Penerapan Konsep Gamifikasi pada Perancangan Aplikasi PembelajaranAl-Quran. STMIK AMIKOM Yogjakarta. Seminar Nasional Teknologi Informasi dan Multimedia: ISSN: 2302-3805.

Rohaila M. R. \& Fariza, K. (2017). Gamifikasi: Konsep dan implikasi dalam pendidikan. Pembelajaran Abad ke-21: Trend Integrasi Teknologi (144-154). Bangi: Fakulti Pendidikan UKM.

Rohwati, M. (2012). Penggunaan pendidikan permainan untuk meningkatkan hasil belajar IPA biologi konsep klasifikasi mahluk hidup. Jurnal Pendidikan IPA Indonesia, 30, 10-55.

Sayed Yusof, S. H., Wee Hoe, T., \& Muhammad Zaffwan, I. (2014). Digital game-based learning for remedial mathematics students: A new teaching and learning approach in Malaysia. International Journal of Multimedia and Uniquitous Engineering, 9(11), 325-338.

Sebastian, D., Dan, D., Rilla, K., \& Lennart, N. (2011). From game design elements to gamefulness: Defining gamification. In Proceedings of the 15th International Academic MindTrek Conference: Envisioning Future Media Environments.

Yin, R. K. (2009). Case study research: Design and methods $\left(4^{\text {th }} E d\right.$.). Thousand Oaks, CA: Sage.

\section{Biographical Statements}

Hanifah MAHAT is a senior lecturer in the Department of Geography \& Environment, Faculty of Human Sciences at Universiti Pendidikan Sultan Idris (UPSI) Malaysia. She previously taught at senior high school level for 11 years, 6 years at teacher training institutes and joining the academic faculty at the University in 2014. Her major fields of research include sustainable education practices and behavior. 
Mohmadisa HASHIM is a senior lecturer in Department of Geography \& Environment, Faculty of Human Science at Universiti Pendidikan Sultan Idris (UPSI) Malaysia. His major fields of research include Hydrology, Physical Geography and Environmental Management.

Saiyidatina Balkhis NORKHAIDi is a postgraduate student undergoing $\mathrm{PhD}$ (Geography) in Department of Geography \& Environment, Faculty of Human Science at Universiti Pendidikan Sultan Idris (UPSI) Malaysia. Her research is more on environmental literacy and numeracy also development of index.

Nasir NAYAN is a senior lecturer in Department of Geography \& Environment, Faculty of Human Science at Universiti Pendidikan Sultan Idris (UPSI) Malaysia. His major fields of research include geographic information systems, GIS, remote sensing, remote sensing, GIS Online, Business Information System, physical geography, human geography, mangroves, coral reefs, ecosystems, ecology, coastal, coastal zones.

Yazid SALEH is a senior lecturer in Department of Geography \& Environment, Faculty of Human Science at Universiti Pendidikan Sultan Idris (UPSI) Malaysia. His major fields of research include sustainable Urban Geography Urban Conservation Cultural and Heritage Tourism Urban Studies.

Nur HAMID is lecturer in Department of Islamic Community Development at Universitas Islam Negeri Walisongo Semarang, Indonesia, and is also the Editor-in-Chief of the International Journal of Social Learning (IJSL). He is a $\mathrm{PhD}$ Candidate in Department of Social Studies (Geography Education) at Universitas Negeri Semarang, Indonesia. He focuses on social studies teaching, disaster education, and geography education.

Nur Hidayah BAHARUDIN is a postgraduate student undergoing master in Department of Social Studies and Citizenship, Faculty of Human Science at Universiti Pendidikan Sultan Idris (UPSI) Malaysia. Her research is more on digital citizenship literacy.

Nurul Afifah MOHD FAUDZI is an undergraduate student undergoing BEd (Geography) in Department of Geography \& Environment, Faculty of Human Science at Universiti Pendidikan Sultan Idris (UPSI) Malaysia. 